\title{
Tyska utflykter i skandinavisk judaistik
}

\author{
BOKRECENSION
}

DOI: https://doi.org/10.30752/nj.107323

Figurationen des Jüdischen. Spurensuchen in der skandinavischen Literatur, utg. Clemens Räthel och Stefanie von Schnurbein. Berliner Beiträge zur Skandinavistik 27 (Berlin: Nordeuropa-Institut, 2020). $336 \mathrm{~s}$.

Figurationen des Jüdischen, som utkommit i serien Berliner Beiträge zur Skandinavistik, utgiven av Nordeuropainstitutet vid Humboldtuniversitetet för att dokumentera forskningen $i$ arbetsgruppen Juden in Skandinavien, är en artikelsamling bestående av I 3 artiklar av sju olika författare med undertiteln Spurensuchen in der skandinavischen Literatur. "Skandinavisch" täcks inte riktigt av artiklarna då nio handlar om dansk, en om norsk och dansk och två om norsk litteratur, medan en undersöker en dansk, en norsk, en svensk och en dansk-judisk författares verk. I sistnämnda bidrag jämförs tre majoritetskvinnors alster med en judes, och eftersom de förstnämnda inte relaterar till judar eller judendom, faller Sverige helt utanför det som ska vara den gemensamma nämnaren för artiklarna. Finland lyser med sin totala frånvaro, men hör ju strikt taget inte till Skandinavien, varför denna avgränsning kan motiveras, även om man kunde hävda att Finland nog kulturellt hör till Skandinavien.

På tre när har artiklarna utkommit tidigare i olika publikationer åren 2004-2015, en av dem i Nordisk Judaistik 2004 (Stefanie

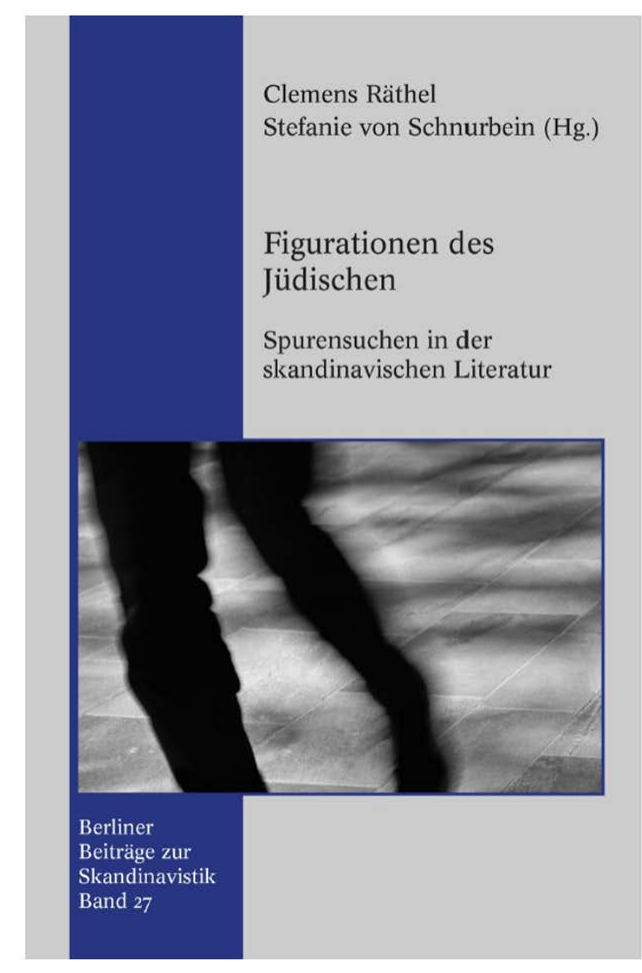

von Schnurbein: "Darstellungen von Juden in der dänischen Erzählliteratur des poetischen Realismus", som inleder samlingen). Av de tidigare opublicerade bidragen har von Schnurbeins "Writing from the margins: new voices in literature, social critique and the novel around I850" godkänts för publicering i USA i lätt modifierad version. Clemens Räthels "'All the world is a stage': theatre and the means of otherness in H. C. Andersen's Lucky Peer and Karen Blixen's The 
Dreamers" är av språket att döma inte skriven för föreliggande utgåva, men har alltså inte nått fram till publicering på annat håll. Räthel är en av utgivarna och står själv för två av bidragen, medan den andra utgivaren von Schnurbein skrivit hela fem av de sammanlagt $\mathrm{I} 3$ artiklarna.

Hennes två inledande artiklar behandlar författarna under den danska litteraturens s.k. gyllene ålder Bernhard Severin Ingemann, Carsten Hauch, Hans Christian Andersen, Thomasine Gyllembourg och Steen Steensen Blicher, vilka alla ska ha gjort judarna till centrala gestalter i sina verk. Anledningen till detta var dels den s.k. judefejden I8 I 3, i vilken en rad författare tog ställning dels mot en flod av antisemitiska inlägg, dels mot våldsamma övergrepp mot judarna som spred sig till Danmark från Tyskland år I 8 I 9 .

Von Schnurbein lyfter fram fenomenen assimilering och ackulturation; skillnaden mellan dem är att gruppmedvetandet vid den förra utplånas medan den vid den senare bevaras. Judeemancipationen aktualiserade dessa vägar. Som känt var assimileringstrenden stark bland de europeiska judarna fram till upptakten till andra världskriget. De teman som ventileras i den av von Schnurbein behandlade litteraturen anknyter dels till judarnas yttre attribut som utseende och språk, dels deras påstådda förmögenhet. Den författare som framträder kanske mest i bidragen om dansk litteratur är Meïr Aron Goldschmidt med sin roman En jøde, som beskriver en judisk mans strävan efter något man kunde placera i gränsmarken mellan ackulturation och assimilering: han vill gifta sig med en kristen danska men inte bli döpt. Till slut misslyckas han med sin strävan.

Joachim Schiedermair analyserar i "Der Kaufmann von Kopenhagen" Thomasine Gyllembourgs novell Jøden, vars egenhet är att sammanväva kvinnoemancipationen och judeemancipationen. Han framhåller dock att ett 80-sidigt avsnitt $i$ den 150 -sidiga novellen har rakt upp och ner ingenting med judarna att göra. Detta motsvarar mitt intryck av den danska avdelningen av Figurationen des Jüdischen: judar figurerar i de analyserade texterna, men på något sätt stannar det vid det. Någon djupare analys förväntar man sig förgäves. Just i förekommande fall ligger felet kanske snarare hos "analysanden" än analytikern. Som Schiedermair skriver: "Inte heller lösningen på frågan [---] leder till någon diskursiv enhet, för förbindelsen förblir av ett ytligt slag... hans [novellfiguren Brancos] judiskhet förblir marginell för lösningen” (s. 75).

Ännu mer fundersam blir jag dock då jag läser Kirsten Wechsels två bidrag om Johan Ludvig Heibergs kamp för införandet av sångspelet, vaudeville, på den danska teaterscenen, "Herkunftstheater: zur Regulierung von Legitimität im Streit um die Gattung Vaudeville" och "Lack of money and good taste: questions of 'value' in Heiberg's vaudevilles”. Det är förstås intressant att läsa om de strikt reglerade förhållandena för dansk scenkonst på I 80o-talet, men kopplingen till det judiska blir några judiska gestalter i Heibergs sångspel utan närmare analys. I hela "Lack of money and good taste" berörs judarna i två på varandra följande stycken; därutöver hänvisas det tre gånger till en rollfigur som "the Jew" eller "Jewish".

Clemens Räthel skriver i "'All the world is a stage': theatre and the means of otherness in H. C. Andersen's Lucky Peer and Karen Blixen's The Dreamers" om Andersens LykkePeer och Blixens The Dreamers (skriven på engelska). Återigen kan det konstateras att i de båda verken finns en judisk figur, men därvid förblir det.

Klaus Müller-Wille väver i "Buchstabentheater: zum Konzept einer modernen jüdischen Poetik in Meïr Aron Goldschmidts Avromche Nattergal (I87I)" ihop tre dansk- 
judiska författare, Henrik Hertz, Meïr Aron Goldschmidt och Georg Brandes. Av dem hade Hertz låtit döpa sig, Goldschmidt motsatte sig assimileringen medan Brandes som ateist inte ville bli betraktad som jude. MüllerWille argumenterar för att Goldschmidt i sitt sena verk Avromche Nattergal polemiserar mot Hertz' romantiska tragedi Sven Dyrings Huus och Brandes' mot honom kritiska essä "M. Goldschmidt". Utrymmet medger inte att bedöma hållbarheten i hans argumentering. Som ett intressant sidospår kan dock nämnas N. F. S. Grundtvigs kritik mot Goldschmidt som går ut på att han behärskar danska språket alltför väl. Denne bevisar enligt Grundtvig sin inte enbart fysiska utan även andliga tillhörighet till "detta märkvärdiga folk" i synnerhet därigenom, att han "skriver danska långt bättre än de flesta s.k. danska författare". Detta ska visa att han betraktar danskan som blott ett medel till att göra sig ömsesidigt förstådd. Inte är det lätt för en jude att bli ackulturerad; bristfälliga kunskaper i nationalspråket hjälper knappast till, men det gäller alltså också att inte lära sig språket alltför bra!

Lite fundersam blir jag då Müller-Wille skriver: "I motsats till den kristna bibelförklaringen (Bibelexegese), som ständigt återkommer till motsatsen mellan ande och bokstav, är den judiska hermeneutiken präglad av kravet på bokstavstrohet" (s. I7I-I72). Som kristen exeget känner jag inte alls igen mig i denna beskrivning. Det verkar som om Müller-Wille ofrivilligt (?) förde vidare fördomar från flydda sekler.

Florian Brandenburg ger sig i "'At Orientaleren skal tale som Orientale...': zur Problematik von Form und Funktion 'jüdischen Sprechens' in M.A. Goldschmidts En jode (I 845/52)" i kast med frågan hur judarnas sätt att tala danska framställs utgående från den för läsaren vid det här laget välbekanta romanen En jøde. Avvikande från bokens övriga artiklar förutsätts läsaren behärska såväl danska som jiddisch, eftersom de använda citaten inte översätts.

Temat är intressant, men på något sätt kommer Brandenburg inte till skott.

Artikeln utmynnar i följande konklusion:

Iscensättningen av figurerna som är skapade med den komiska scenjuden som förebild, uppfyller [---] tre funktioner:

I) Genom överskridning av genregränser åstadkommer de en känsla av obehag gentemot berättarstrategin inom det för tolkningen av romanen centrala slutkapitlet.

2) De etablerar ett ultimativt kontrautkast till den misslyckade protagonisten.

3) De rubbar genom en dubbelkodning respektive den genrespecifika figurgestaltningens sammanbrott förtroendet för den litterära representationen av judiska figurer och kan avslöja dessa som fiktiva. (s. 2 I I-2 I 2)

Så nu vet vi det.

Von Schnurbein återkommer med ytterligare tre artiklar. I "Kampf um Subjektivität: Nation, Religion und Geschlecht in zwei dänischen Romanen um I 850 ” uppehåller hon sig kring det faktum att Meïr Aron Goldschmidt, författaren till En jøde som vi alltså möter igen, inte var villig att understöda Mathilde Fibiger, som skrivit Clara Raphael, i hennes kvinnoemancipatoriska strävanden, istället för att i kvinnoemancipationen se en bundsförvant till judeemancipationen. Von Schnurbein förklarar detta med att Goldschmidt inte behövde kvinnorna som författare, "utan snarare i deras funktion som traditionella kvinnor utan 'manlig' bildning och en egen röst. Detta är förutsättningen för honom att själv bli en fullvärdig borgerlig man" (s. 230).

I"Writing from the margins: new voices in 
literature, social critique and the novel around I 85 o"laborerar von Schnurbein med romaner av Fredrika Bremer (Sverige), Camilla Collett (Norge), Mathilde Fibiger (Danmark) och surprise, surprise - Meïr Aron Goldschmidts En jøde. Detta är enda gången i boken som Sverige berörs. Den gemensamma nämnaren för dessa är deras emancipatoriska syfte. Hon konstaterar:"... the tendencies of the women writers and the Jewish writer diverge due to the different mechanisms of exclusion the respective groups are subject to" (s. 239). Det är känt att jude- och kvinnoemancipationen sammanföll tidsmässigt, t.ex. i Finland fick kvinnorna rösträtt I 906 och judarna medborgerliga rättigheter I9I7. Men på något sätt blir det nu så att Goldschmidt kör sitt eget race i förhållande till de tre kvinnorna. Dessa å ena sidan och Goldschmidt å den andra blir en återkommande uppställning.

Till slut öppnar von Schnurbein den avslutande Norge-sektionen i boken med "Literarischer Antisemitismus bei Knut Hamsun und Henrik Pontoppidan: Zwei Varianten mit unterschiedlicher Tendenz" (Pontoppidan var dansk men ägnas mycket mindre utrymme i artikeln). Hamsun visar sig vara en het potatis för forskare i norsk litteratur. Allen Simpson skrev år I 977 en analys av Hamsun som von Schnurbein rankar som "det kanske enda vetenskapliga bidraget som placerar Hamsuns uttalanden om judar i en vidare kontext av europeisk antisemitism som konstruerar judarna som icke-européer och orientaler" (s. 260). I 986 kritiserade Dolores Buttry Simpson genom att argumentera för att Hamsuns kritik av judarna helt enkelt var berättigad. Buttry har fått talrika efterföljare medan Simpson fått iklä rollen som Hamsunforskningens strykpojke.

Egentligen handlar artikeln om negativa stereotypier om judarna i de analyserade verken. Särskilt mycket analys ges dock inte. Avslutningsvis konstateras att vi här möter en särskilt eklatant forskningsuppgift som i den skandinaviska och skandinavistiska kontexten tas upp endast långsamt.

Katharina Bock skriver i "Der Jude. Neun blühende Dornenzweige - Henrik Wergelands Dichtung gegen den 'Judenparagraphen' in der norwegischen Verfassung von I8I4", som inte publicerats tidigare, om diktarens kamp för att avskaffa en ödesdiger anomali i den norska grundlagen som Stortinget i Eidsvoll antog år i 814. Grundloven gällde för att vara liberalast rentav i hela världen. Icke desto mindre lydde paragraf 2: "Den evangelisk-lutterske Religion forbliver Statens offentlige Religion. De Indvaanere, der bekjende sig til den, ere forpligtede til at opdrage sine Børn i samme. Jesuitter og Munkeordener maae ikke taales. Jøder ere fremdeles udelukkede fra Adgang til Riget."

Samma år beviljade Danmark, som Norge just lösgjorde sig från, judarna närapå fulla medborgerliga rättigheter!

Paragrafen följdes minutiöst. År I 8 I 7 råkade ett fartyg i sjönöd utanför den norska kusten och måste angöra i Norge. Ombord fanns en polsk jude som sattes under polisuppsikt och förvisades till Sverige. Poeten och teologen Henrik Wergeland lämnade I839 in ett förslag till Stortinget om att stryka meningen om judarna från paragraf 2. Samtidigt delade han ut till varje ledamot ett exemplar av sin för ändamålet författade diktsamling Jøden. Ni blomstrende torneqviste. Förslaget fick majoritet, men inte de för grundlagsändringar erforderliga två tredjedelar. Wergeland inlämnade I842 ett nytt förslag med samma innehåll, och gav I 844 ut en andra diktsamling för att påverka utgången, Jødinden. Elleve blomstrende torneqviste. Slutligen godkändes förslaget I $85 \mathrm{I}$, men då var Wergeland redan död sedan I 845 .

Bock analyserar Wergelands dikter och kommer till slutsatsen att det egentligen inte handlar om judarna, utan i första hand 
om nationella frågor, om Norges politiska positionering inom Europa, om den riktiga utläggningen av kristendomen och det eskatologiska hoppet om en förening mellan kristendomen och judendomen. Dikterna formulerar motbilder till judiska stereotyper som är klichéer och trots den goda avsikten i sin schablonmässighet problematiska.

Bock förvånar sig över att Eva i Jødinden liknas vid en drottning, "då ju Eva för både den kristna och den judiska teologin snarare gäller som den första syndaren" (s. 300). Härvidlag förbiser hon dock att syndafallet inte spelar samma negativa roll i judisk teologi som i kristen teologi. Betoningen ligger snarare i människans vuxenblivande.

Artiklarna avslutas med Clemens Räthels "'Gibt es denn hier niemanden, der weiß, wie ein Jude aussieht?' Adolph Rosenkildes Drama Ein Jude in Mandal und die Auseinandersetzungen um die rechtliche Stellung der Juden in Norwegen”. Dramat är ett sångspel från I 849, då alltså nämnda paragraf $2 \mathrm{i}$ Grundloven behandlades i Stortinget för att slutligen avskaffas I 85 I. Det uppstår kalabalik i Mandal, en småstad vid Norges sydspets, då det visar sig att en jude vistas i staden. I detta sammanhang ställs frågan: finns här då ingen som vet hur en jude ser ut, vilken de församlade stadsborna besvarar med ett unisont "nej". En ung student vet dock att ge besked, och så grips juden och utvisas. Sedan visar det sig dock, att det är samme student som förklätt sig till jude enligt sin egen beskrivning, eftersom han behövde få lämna Mandal men inte tilläts göra det.

Figurationen des Jüdischen ger många intressanta inblickar i den judiska närvaron i I8oo-talets Danmark och Norge. Samtidigt är en del av artiklarna väl löst knutna till bokens tema då det tycks räcka med någon flyktig hänvisning till judarna för att platsa i samlingen. Författarna är skandinavister - åtminstone Räthels och Bocks doktorsavhandlingar har ett judaistiskt tema - som gör en utflykt till judaistiken. I det stora hela lyckas de väl, men ibland blir det lite väl mycket skandinavistik på judaistikens bekostnad, och några enstaka yttranden vittnar om bristande kännedom om judendomen.

En hel del överlappning mellan artiklarna kan påtalas. Dessutom förekommer en del hänvisningar till andra bidrag som ingår i samlingen, som kunde ha kompletterats med angivelser av sidnumren i nyutgåvan; det hade varit trevligt då man nu en gång håller den i sin hand.
RISTO NURMELA

Docent, teol.dr Åbo Akademi 